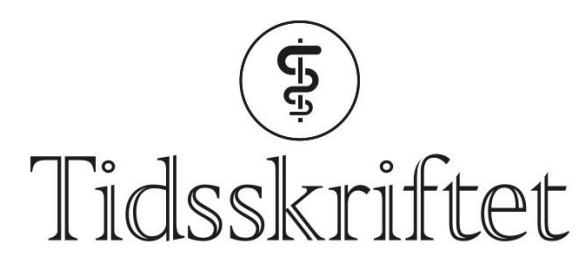

DEN NORSKE LEGEFORENING

\title{
Fjesingforgiftning
}

TIDLIGERE I TIDSSKRIFTET

\section{JULIE DIDRIKSEN}

Tidsskriftet

Trachinus draco, bedre kjent som fjesing her til lands, er en fisk som vanligvis blir rundt 20-30 cm lang i norske farvann. Den liker å grave seg ned i sanden på grunt vann, slik at bare øynene stikker opp, og så snapper den opp uheldige byttedyr som kommer forbi. Den store piggen på gjellelokket er giftig, det samme gjelder de to første piggene på ryggfinnen. Og selv om den vanligvis ikke trives på grunt nok vann til å være et problem for badende, forekommer forgiftninger hos fiskere. I Tidsskriftet nr. 7/1966 finner vi en artikkel om temaet, under følger et utdrag (Tidsskr Nor Lægeforen 1966; 86: 448-52).

\section{Forgiftning med fjesing i norske farvann}

\section{AV OLE DANBOLT MJØS}

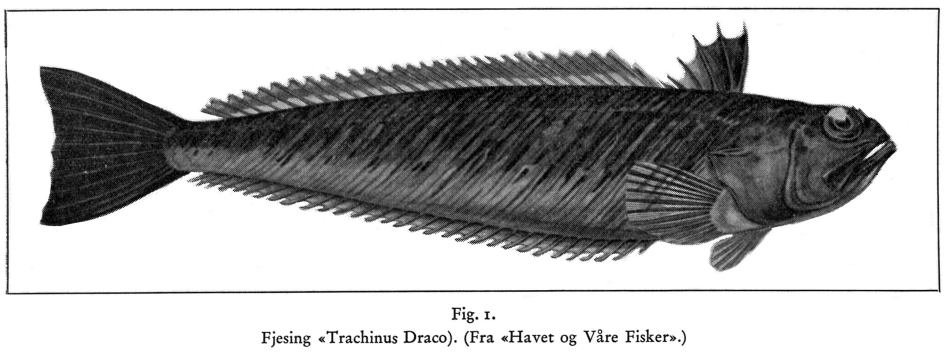

Skeie inndeler fjesingstikk etter sykdomsforløp:

1. Ukompliserte tilfelle.

2. Kompliserte tilfelle (etter hyppighet).

1. Infeksjon.

2. Ischemisk, aseptisk nekrose.

3. Irreversible vevsforandringer.

4. Kjemisk bursitt eller tendinitt

5. Refleksdystrofi.

6. Tetanus. 
De aller fleste forgiftningstilfellene i den danske undersøkelsen var ukompliserte.

Skeie har påvist at giften er av protein-karakter, at den kan ekstraheres med spesiell metodikk, og at den kan styrkebestemmes. Han har påvist at det er mulig å lage et serum og en vaksine mot fjesingstikk, «men at det vil støte på store vanskeligheter med fremskaffelse av de nødvendige mængder råtoxin». (...)

Da yrkesfiskere kjenner til fjesingen og dens giftighet, garderer de seg mot stikk ved forskjellige forsiktighetsregler

Ved forespørsler, intervjuer og meddelelser har det lykkes å oppspore minst 7 personer som er stukket av fjesing i disse farvann med mer eller mindre uttalte forgiftningssymptomer til følge, uten at sykehusinnleggelse fant sted. To av disse personene var yrkesfiskere. (...)

Da yrkesfiskere kjenner til fjesingen og dens giftighet, garderer de seg mot stikk ved forskjellige forsiktighetsregler. (...) Det er derfor temmelig sjelden at yrkesfiskere blir stukket av fjesing, selv om de har drevet fiske på sør- og sørvestkysten av Norge i opptil 40 år på det meste. Imidlertid kjenner de fleste til ett eller flere tilfelle av forgiftning med fjesing $\mathrm{i}$ distriktet, uten at ytterligere opplysninger foreligger. (...)

Det foreligger for tiden ingen spesifikk behandling ved fjesingforgiftning. (...) Den symptomatiske behandling av pasientene i dette materiale har vært nokså ensartet: Sterke analgetica, penicillin profylaktisk for å motvirke sekunderinfeksjon, til dels også antihistaminica og kalsiumglykonat intravenøst ved ferske tilfelle.

De fleste tilfelle går over av seg selv eller blir 'behandlet' ved egen hjelp

Andre midler som har vært anbefalt fra medisinsk hold, er innsprøytning av oksydasjonsmidler, spesielt $5 \%$ kaliumpermanganatoppløsning i stikkåpningen og omgivelsene, for om mulig å få giften destruert på denne måte. En annen metode er injeksjon av lokalanæsthetica i stikkregionen. Enkelte av de folkemedisinske råd ved forgiftning med fjesing brukes også undertiden: tourniquet proksimalt for stikkåpningen, incisjon og skylling av såret. (...)

Graden av forgiftning varierer med innsprøytet giftmengde, mottagelighet hos den stukne og tiden før instituert behandling. De fleste tilfelle går over av seg selv eller blir «behandlet» ved egen hjelp uten at lege eller sykehus blir implisert.

Publisert: 7. oktober 2019. Tidsskr Nor Legeforen. DOI: 10.4045/tidsskr.19.0186

(C) Tidsskrift for Den norske legeforening 2020. Lastet ned fra tidsskriftet.no 